\title{
Changes in the West African landscape at the end of the African Humid Period
}

\author{
Anne-Marie Lézine \& Kévin Lemonnier \\ Laboratoire d'Océanographie et du Climat, Expérimentation et Approche \\ numérique/IPSL, Sorbonne Université, CNRS-IRD-MNHN, Paris, France
}

Martyn P. Waller

Department of Geography and Geology, Kingston University London, Kingston upon Thames, Surrey, United Kingdom

\author{
Ilham Bouimetarhan ${ }^{1} \&$ Lydie Dupont \\ Center for Marine Environmental Sciences, MARUM, University of Bremen, \\ Bremen, Germany
}

African Pollen Database contributors ${ }^{2}$

\begin{abstract}
Existing pollen datasets from northern Africa stored in the African Pollen Database were used to assess changes in landscape physiognomy at the end of the African Humid Period (AHP) from $5000 \mathrm{cal}$ yr BP to the present using arboreal pollen percentages. The thirty-six sites available were used to map changes in arboreal cover at a sub-continental scale. Based on their location in present-day forested and non-forested areas and their relatively higher temporal resolution eight of them were selected to examine the timing and amplitude of the vegetation response in more detail, and particularly in the Sahel. In spite of low pollen production and dispersal of many tropical plants, which lead to the under representation of most of the trees relative to their abundance in the landscape, we were able to distinguish the geographical pattern and timing of vegetation changes. The landscape response to the end of the AHP was far from homogeneous particularly in the Sahel where a clear east-west gradient of changing tree cover is indicated with the central Sahel being notably species poor. In areas where forests were well developed during the AHP, i.e. in the south and west, the establishment of the modern landscape was abrupt with a threshold crossed between 3300 and 2500 cal yr BP according to local conditions. Elsewhere in northern Africa the switch from tree $\left(\mathrm{C}_{3}\right)$ to grass $\left(\mathrm{C}_{4}\right)$ dominated landscapes occurred more gradually during the same period. This review shows that the timing of the ecosystem response at the end of the AHP was remarkably synchronous throughout northern Africa.
\end{abstract}

\footnotetext{
${ }^{1}$ Other affiliation: Faculté des Sciences appliquées, CUAM, Université Ibn Zohr, B.P. 8106 Agadir, Morocco

${ }^{2}$ Akaegbobi, I.M., Assi-Kaudjhis, C., Ballouche, A., Buchet, G., Kadomura, C., Lebamba, J., Maley, J., Marchant, R., Mariotti Lippi, M., Médus, J., Mercuri, A.M., Njokuocha, R.C., Roche, E., Salzmann, U., Schulz, E., Sowunmi, A., Tossou, M., Vincens, A.
} 


\subsection{INTRODUCTION}

Reconstructing vegetation changes in tropical North Africa during the Holocene and understanding how the landscape has evolved from a 'humid' state characterized by the development of numerous lakes and wetlands into the today's hyper-arid desert continues to be the subject of extensive research (e.g. Dallmeyer et al. 2020; Krinner et al. 2012; Lézine et al. 2011; Shanahan et al. 2015). Pollen data have been successfully used to assess biodiversity changes that occurred during the African Humid Period (AHP) (deMenocal et al. 2000) such as the penetration of tropical trees into the Sahara and the Sahel at its onset or their retreat at its termination (e.g. Hély et al. 2014 and references therein). Pollen data are however extremely complex and changes in plant cover and related land-surface albedo remain difficult to be quantified. A large part of this complexity is due to the uneven geographical distribution of the data, difficulties in establishing robust chronologies, and the incomplete and/or discontinuous nature of the sedimentary series (Watrin et al. 2009). The desiccation of the ancient Saharan lakes and the deflation of exposed lacustrine deposits, still continuing today, have eroded lake sediments and considerably hampered the preservation of pollen grains. Therefore, preserved sediments provide limited time windows mainly concentrated in wettest periods. Only a single, continuous, sequence covering a time interval from the end of the AHP to the present is available for the entire Sahara (Lézine et al. 2011). Continuous pollen series with high temporal resolution are however more numerous to the south, from the Sahel to the Congo basin (e.g. Lézine et al. 2013a; Maley and Brenac 1998; Ngomanda et al. 2009; Salzmann et al. 2002; Vincens et al. 2010; Waller et al. 2007).

Differences in pollen production and dispersal between tropical plants means that interpretation of vegetation cover within the landscape from ancient pollen records is further complicate, especially in the driest regions. Most of the trees have a low pollen productivity, disperse pollen entomophilously, and are thus under-represented in the pollen spectra (Ritchie 1995). While the presence of tree pollen, even a single grain, may be indicative of the presence of the corresponding plants (Watrin et al., 2006), it is extremely difficult given the current state of knowledge, to quantify the importance of these trees in the landscape. Therefore, the timing and magnitude of the environmental change related to the end of the AHP remains poorly documented.

Here we use a simple index: the percentage of tree pollen (AP \%) from selected high resolution pollen records from both continental and marine environments in northern Africa, from $5^{\circ}$ to $19^{\circ} \mathrm{N}$, in order to characterize the environmental change at the end of the AHP. This index is commonly used to qualitatively evaluate woody cover in temperate regions where most of the tree species are wind-pollinated. Our goal is to discuss how well this index can be applied to northern Africa, given the particularities of the pollen production and dissemination syndromes of tropical tree species.

\subsection{ENVIRONMENTAL SETTING}

The climatic features of northern Africa are related to the Atlantic monsoon circulation and the seasonal migration of the Intertropical Convergence Zone (ITCZ). In January, the monsoons' influence is confined to the periphery of the Gulf of Guinea and the northernmost areas are subject to the hot, dry continental trade winds. In July, the ITCZ reaches its northernmost position at $22^{\circ} \mathrm{N}$ allowing moist monsoon air to extend over north tropical Africa up to the southern fringe of the Sahara.

The progressive decrease of the monsoon influence and related rainfall on the continent is correlated with the latitudinal distribution of the vegetation. Five major floristic regions can be delineated from south to north: Guineo-Congolian forests of different types (evergreen and semievergreen forests) and secondary wooded grasslands (mean annual rainfall more than $1200 \mathrm{~mm}$ ), Sudanian dry forests and wooded grasslands $\left(1500-500 \mathrm{~mm} \mathrm{yr}^{-1}\right)$, Sahelian wooded grasslands 


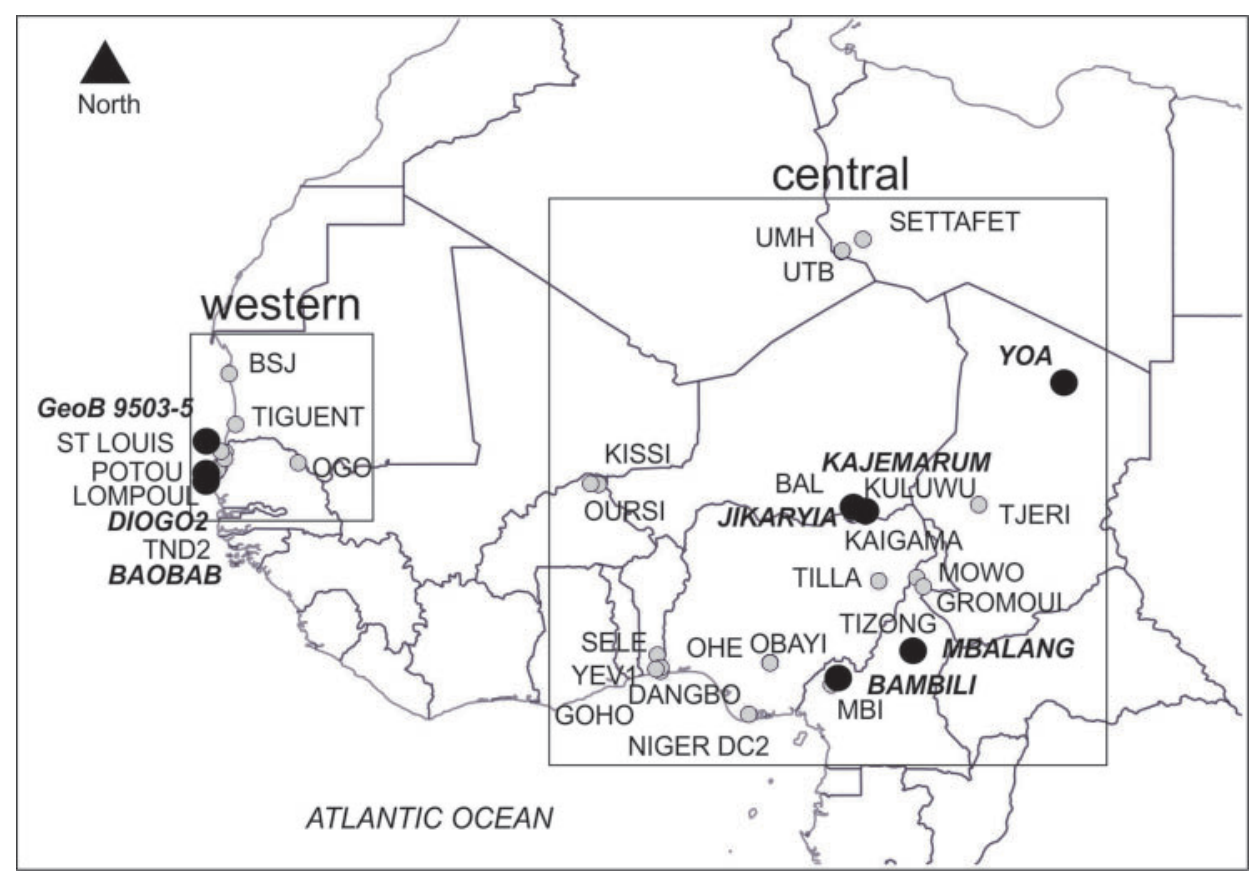

Figure 1. Location map of the Holocene pollen sites used in this study (Table 1). In bold and italic, pollen sites detailed in the text (Figure 3). Boxes define the two sectors shown in Figure 5.

and grasslands (500-100 $\mathrm{mm} \mathrm{yr}^{-1}$ ) and Saharan steppes (less than $100 \mathrm{~mm} \mathrm{yr}^{-1}$ ) (White 1983) (Figure 1). In addition, Afromontane forests occur in the Cameroon Volcanic Line between roughly 1800-2300 $\mathrm{m}$ asl (annual rainfall: $2000 \mathrm{~mm} \mathrm{yr}^{-1}$; mean temperature: $18^{\circ} \mathrm{C}$ ) bordered at upper elevations by Afroalpine grasslands and at lower elevations by sub-montane forests and wooded grasslands.

Along the coast, mangrove forests expand at the mouth of rivers where they benefit from both brackish waters and large muddy areas. Their optimal growth is attained under a rain forest climate but two main components expand northward along the coast of West Africa: Rhizophora racemosa reaches its northern limit at the mouth of the Senegal River near $16^{\circ} \mathrm{N}$ and Avicennia germinans extends up to Tidra at $19^{\circ} 50 \mathrm{~N}$.

\subsection{DATA USED}

In this study, we use all the available Holocene pollen data from northern Africa stored in the African Pollen Database (APD) (Figure 1; Table 1). We focus on changes in landscape physiognomy, i.e. the shift from a $\mathrm{C}_{3}$ plant dominated landscape to a $\mathrm{C}_{4}$ plant dominated one at the end of the AHP. Therefore, pollen records from equatorial lowland forests (e.g. Elenga et al. 1994, 1996; Reynaud-Farrera et al. 1996) were excluded, since the impact of the environmental crisis, which occurred at the end of the AHP in the Congo Basin, was more a change in forest composition and density than the replacement of lowland forests by grasslands or wooded grasslands (Vincens et al. 1999). The dataset consists of 36 sites among which seven continental (Bambili, Mbalang, Diogo, Mboro-Baobab, Kajemarum, Jikaryia, Yoa) and one marine (GeoB 9503-5) pollen records have been selected in order to characterize the evolution of the landscape in the 
Table 1. List of the pollen sites used in this study according to latitude from north to south in the two sectors defined in this study. In bold and italic $=$ selected sites, see black dots on Figure 1 .

\begin{tabular}{|c|c|c|c|c|c|c|}
\hline Site name & Latitude & Longitude & $\begin{array}{l}\text { Altitude } \\
\text { (m asl) }\end{array}$ & Country & $\begin{array}{l}\text { Time } \\
\text { frame } \\
\text { (cal yr BP) }\end{array}$ & Reference \\
\hline \multicolumn{7}{|c|}{ Central sector } \\
\hline SETTAFET & 25.35 & 11.43 & 1100 & Libya & 5000 & Schulz (1980) \\
\hline $\begin{array}{l}\text { UAN TABU } \\
\text { [UTB] }\end{array}$ & 24.86 & 10.52 & 915 & Libya & $4000-4250$ & $\begin{array}{l}\text { Mercuri, and } \\
\text { Grandi (2001) }\end{array}$ \\
\hline $\begin{array}{l}\text { UAN } \\
\text { MUHUGGIAG } \\
\text { [UMH] }\end{array}$ & 24.84 & 10.51 & 915 & Libya & $4000-4250$ & $\begin{array}{l}\text { Mercuri et al. } \\
\text { (1998) }\end{array}$ \\
\hline$\underline{Y O A}$ & 19.03 & 20.31 & 380 & Chad & $0-5000$ & $\begin{array}{l}\text { Lézine et al. } \\
\text { (2011) }\end{array}$ \\
\hline OURSI & 14.65 & -0.49 & 290 & $\begin{array}{l}\text { Burkina } \\
\text { Faso }\end{array}$ & $0-3500$ & $\begin{array}{l}\text { Ballouche and } \\
\text { Neumann } \\
\text { (1995) }\end{array}$ \\
\hline KISSI & 14.62 & -0.14 & 280 & $\begin{array}{l}\text { Burkina } \\
\text { Faso }\end{array}$ & $500-750$ & $\begin{array}{l}\text { Ballouche } \\
\text { (1997) }\end{array}$ \\
\hline TJERI & 13.73 & 16.50 & 275 & Chad & $500-4750$ & $\begin{array}{l}\text { Maley } \\
(2004)\end{array}$ \\
\hline$\underline{J K A R Y I A}$ & 13.31 & 11.08 & 343 & Nigeria & $0-5000$ & $\begin{array}{l}\text { Waller et al. } \\
\text { (2007) }\end{array}$ \\
\hline BAL & 13.30 & 10.94 & 300 & Nigeria & $250-5000$ & $\begin{array}{l}\text { Salzmann and } \\
\text { Waller (1998) }\end{array}$ \\
\hline KAJEMARUM & 13.30 & 11.02 & 300 & Nigeria & $2750-5000$ & $\begin{array}{l}\text { Salzmann and } \\
\text { Waller (1998) }\end{array}$ \\
\hline KAIGAMA & 13.25 & 11.57 & 330 & Nigeria & $3500-5000$ & $\begin{array}{l}\text { Salzmann and } \\
\text { Waller (1998) }\end{array}$ \\
\hline KULUWU & 13.22 & 11.55 & 330 & Nigeria & $4750-5000$ & $\begin{array}{l}\text { Salzmann and } \\
\text { Waller (1998) }\end{array}$ \\
\hline MOWO & 10.60 & 13.99 & 574 & Cameroon & $500-750$ & $\begin{array}{l}\text { Delneuf and } \\
\text { Médus (1997) }\end{array}$ \\
\hline TILLA & 10.39 & 12.12 & 690 & Nigeria & $0-5000$ & $\begin{array}{l}\text { Salzmann et al. } \\
\text { (2002) }\end{array}$ \\
\hline GROMOUI & 10.32 & 14.32 & 430 & Cameroon & $1000-1250$ & $\begin{array}{l}\text { Delneuf and } \\
\text { Médus (1997) }\end{array}$ \\
\hline MBALANG & 7.32 & 13.73 & 1110 & Cameroon & $0-5000$ & $\begin{array}{l}\text { Vincens et al. } \\
(2010)\end{array}$ \\
\hline TIZONG & 7.25 & 13.58 & 1160 & Cameroon & $0-4000$ & $\begin{array}{l}\text { Lebamba et al. } \\
\text { (2016) }\end{array}$ \\
\hline LAC SELE & 7.15 & 2.43 & 11 & Benin & $0-5000$ & $\begin{array}{l}\text { Salzmann and } \\
\text { Hoelzmann } \\
(2005)\end{array}$ \\
\hline OBAYI & 6.82 & 7.37 & 550 & Nigeria & $1750-2000$ & $\begin{array}{l}\text { Njokuocha } \\
(2012)\end{array}$ \\
\hline OHE POND & 6.80 & 7.37 & 1502 & Nigeria & $1250-1500$ & $\begin{array}{l}\text { Njokuocha and } \\
\text { Akaegbobi } \\
\text { (2014) }\end{array}$ \\
\hline
\end{tabular}


Table 1. Continued.

\begin{tabular}{|c|c|c|c|c|c|c|}
\hline Site name & Latitude & Longitude & $\begin{array}{l}\text { Altitude } \\
\text { (m asl) }\end{array}$ & Country & $\begin{array}{l}\text { Time } \\
\text { frame } \\
\text { (cal yr BP) }\end{array}$ & Reference \\
\hline DANGBO & 6.60 & 2.59 & 40 & Benin & $0-5000$ & Tossou (2002) \\
\hline YÉVIÉDIÉ & 6.53 & 2.37 & 53 & Benin & $1250-5000$ & Tossou (2002) \\
\hline GOHO & 6.44 & 2.57 & 35 & Benin & $750-4750$ & Tossou (2002) \\
\hline MBI & 6.08 & 10.35 & 2018 & Cameroon & 0-5000 & $\begin{array}{l}\text { Lézine et al. } \\
\text { (2021) }\end{array}$ \\
\hline$\underline{B A M B I L I 1}$ & 5.94 & 10.24 & 2273 & Cameroon & $0-5000$ & $\begin{array}{l}\text { Lézine et al. } \\
\text { (2013a) }\end{array}$ \\
\hline $\begin{array}{l}\text { NIGER } \\
\text { DELTA [DC2] }\end{array}$ & 4.55 & 6.43 & 0 & Nigeria & $500-3750$ & $\begin{array}{l}\text { Sowunmi } \\
\text { (1981) }\end{array}$ \\
\hline \multicolumn{7}{|c|}{ Western sector } \\
\hline $\begin{array}{l}\text { BAIE SAINT } \\
\text { JEAN [BSJ] }\end{array}$ & 19.47 & -16.30 & 1 & Mauritania & $1750-3750$ & $\begin{array}{l}\text { Unpublished } \\
\text { (Lézine A.M.) }\end{array}$ \\
\hline TIGUENT & 17.25 & -16.02 & 8 & Mauritania & $3000-3250$ & $\begin{array}{l}\text { Médus and } \\
\text { Barbey (1979) }\end{array}$ \\
\hline$\underline{\text { GeoB 9503-5 }}$ & 16.07 & -16.65 & -50 & $\begin{array}{c}\text { Atlantic } \\
\text { Ocean }\end{array}$ & $1500-4250$ & $\begin{array}{c}\text { Bouimetharhan } \\
\text { et al. (2009) }\end{array}$ \\
\hline ST LOUIS & 16.03 & -16.48 & 2 & Senegal & $0-1000$ & $\begin{array}{l}\text { Fofana et al. } \\
(2020)\end{array}$ \\
\hline POTOU & 15.75 & -16.50 & 11 & Senegal & $0-5000$ & Lézine (1988) \\
\hline OGO [OS2] & 15.57 & -13.28 & 15 & Senegal & $750-1000$ & $\begin{array}{l}\text { Feller et al. } \\
\text { (1981) }\end{array}$ \\
\hline LOMPOUL & 15.42 & -16.72 & 3 & Senegal & $2000-5000$ & Lézine (1988) \\
\hline DIOGO 2 & 15.27 & -16.80 & 8 & Senegal & $250-5000$ & Lézine (1988) \\
\hline $\begin{array}{l}\overline{\text { TOUBA }} \\
\text { N'DIAYE } 2 \\
\text { [TND2] }\end{array}$ & 15.17 & -16.87 & 6 & Senegal & $1000-5000$ & Lézine (1988) \\
\hline$\frac{\text { MBORO- }}{B A O B A B}$ & 15.15 & -16.91 & 4 & Senegal & $0-4500$ & $\begin{array}{l}\text { Lemonnier and } \\
\text { Lézine } \\
\text { (this volume) }\end{array}$ \\
\hline
\end{tabular}

two main vegetation types which expanded in northern Africa during the AHP: (i) continuous forests in the Cameroon Highlands, and (ii) gallery forests around water bodies in the Sahara and Sahel within a dry, open regional environment. The whole dataset was then used to map landscape changes at a sub-continental scale.

The chronology is given in calendar years BP (cal yr BP) after conversion of ${ }^{14} \mathrm{C}$ dates to calendar age according to Stuiver et al. (2020). The age models were retrieved from the published articles or from the APD (i.e. based on linear interpolation between the dated samples) taking into account possible discontinuities in sediment deposition. Arboreal pollen types (AP) include trees, shrubs, palms and lianas. Undifferentiated pollen types (UP) include taxa corresponding to plants with various life forms (trees, shrubs, lianas or herbs) and taxa determined at a low taxonomic level, typically the family level (Vincens et al. 2007). Percentages are calculated against a sum of total pollen excluding those of aquatics (including Cyperaceae), cultivated and Mediterranean plant types. 


\subsection{POLLINATION SYNDROMES OF THE TROPICAL PLANTS}

The pollination syndromes of the families represented at the seven selected sites (Table 2) are derived from Watson and Dallwitz (1992) and the gymnosperm database (www.conifers.org). This reveals the major challenge of representing landscapes from pollen data in northern Africa. Most of the families present in our pollen records are entomophilous or zoophilous (mainly cheiropterophilous and ornithophilous), whereas $16 \%$ are anemophilous or entomophilous and only $5 \%$ are strictly anemophilous. Most of the entomophilous/zoophilous plants produce small amounts of pollen, which may be exceptionally large. As a result, they are under-represented (e.g. Adansonia) or rarely (e.g. Isoberlinia, Daniellia) represented in the pollen assemblages (Watrin et al., 2006). In contrast, members of the Poaceae family, which is exclusively anemophilous, produce large quantities of pollen, and therefore largely dominate the pollen assemblages, particularly those derived from wooded grasslands and grasslands. Taking into account these specifications and the difficulties of measuring the quantity of pollen grains produced by the plants, the most widely used method for describing the pollen signature of the modern vegetation in terms of diversity, biomes or vegetation types is that of surface samples, either from soil, mosses or pollen traps. This method has been successfully developed in tropical Africa since Hedberg (1954). Gajewski et al. (2002) have validated the APD dataset, which covers all of sub-Saharan Africa.

\subsection{POLLEN REPRESENTATION OF THE MODERN LANDSCAPE}

In northern Africa the pollen-plant and pollen-biome relationships have been extensively studied (e.g. Lézine et al. 2009; Watrin et al. 2007 and references therein). These studies have identified the pollen signature of common plants and biomes along latitudinal (Lézine et al. 2009) or altitudinal gradients (Verlhac et al. 2018) in order to provide the basis for reliable vegetation reconstructions in the past and for quantitative estimates of climate parameters from pollen data. However, the physiognomy of the vegetation is only rarely addressed (Lézine and Hooghiemstra 1990; Vincens et al. 2000). Based on arboreal pollen percentages (AP\%) and undifferentiated pollen percentages (UP\%), Figure 2A shows that the two extreme vegetation types along a southnorth transect in northern Africa, the Guineo-Congolian forest in the south and the desert steppe in the north, are easily identified (Lézine and Hooghiemstra 1990). The Guineo-Congolian forest is represented by AP higher than $80 \%$ and UP lower than $8 \%$ while the desert steppe is represented by AP lower than $10 \%$. In desert steppe, UP (mainly herbs, sub-shrubs or shrubs from the Amaranthaceae, Brassicaceae, Caryophyllaceae, Asteraceae families) values are exceptionally high, representing more than $50 \%$. While AP\% consistently range between $20 \%$ and $50 \%$ in the Sudanian dry forests of southern Senegal, they strongly vary between 5 and $35 \%$ in the Sahelian woodlands and wooded grasslands, making the pollen signature of the tree cover in these grass-dominated landscapes difficult to detect. The difficulty in detecting tree cover is mainly due to the uneven distribution of the trees within the landscape. This is particularly the case in the transition zone between forest and desert where trees are mostly concentrated along rivers and wetlands (Trochain 1940; White 1983). In addition, these vegetation formations share numerous tree species, the distribution of which is denser in the woodlands and sparser in the wooded grasslands (e.g. Combretaceae, Acacia). The characteristics of their pollen production and dispersal hampers any reliable reconstruction of vegetation types.

In the Equatorial regions, the forest-wooded grassland transect of Kandara (Vincens et al. 2000 ) shows AP higher than $60 \%$ in the forest. AP dramatically decrease to less than $10 \%$ in the adjacent wooded grassland and the transition between the two is typified by intermediate values (45\%) (Figure 2B). However, as stated by the authors, the different kind of forests (Albizia forest and Rinorea forest) cannot be distinguished, and no decrease in AP\% is observed in the forest 
Table 2. List of the families encountered in the Holocene pollen sites used in this study (Table 1) and included in the pollen sum with their pollination syndromes (after Watson and Dallwitz (1992) and the gymnosperm database (www.conifers.org)).

\begin{tabular}{|c|c|c|c|}
\hline Family & Pollination system & Family & Pollination system \\
\hline Acanthaceae & entomophilous & Liliaceae & entomophilous \\
\hline Aizoaceae & entomophilous & Lobeliaceae & entomophilous \\
\hline Alangiaceae & entomophilous & Loganiaceae & entomophilous \\
\hline Amaranthaceae & entomophilous & Loranthaceae & $\begin{array}{l}\text { entomophilous, } \\
\text { or ornithophilous }\end{array}$ \\
\hline Anacardiaceae & entomophilous & Lythraceae & entomophilous \\
\hline Annonaceae & entomophilous & Malpighiaceae & entomophilous \\
\hline Apiaceae & entomophilous & Malvaceae & entomophilous \\
\hline Apocynaceae & entomophilous & Melastomataceae & $\begin{array}{l}\text { entomophilous, } \\
\text { or ornithophilous, } \\
\text { or cheiropterophilous }\end{array}$ \\
\hline Aquifoliaceae & entomophilous & Meliaceae & entomophilous (usually) \\
\hline Araliaceae & entomophilous & Melianthaceae & $\begin{array}{l}\text { entomophilous, } \\
\text { or ornithophilous }\end{array}$ \\
\hline Asclepiadaceae & entomophilous & Menispermaceae & unknown \\
\hline Asparagaceae & entomophilous & Mimosaceae & $\begin{array}{l}\text { entomophilous, } \\
\text { or ornithophilous, } \\
\text { or cheiropterophilous, } \\
\text { or anemophilous }\end{array}$ \\
\hline Asteraceae & $\begin{array}{l}\text { entomophilous (mostly), } \\
\text { or anemophilous }\end{array}$ & Moraceae & $\begin{array}{l}\text { anemophilous, } \\
\text { or entomophilous }\end{array}$ \\
\hline Balanitaceae & $\begin{array}{l}\text { entomophilous } \\
\text { (mostly), or } \\
\text { anemophilous }\end{array}$ & Myricaceae & anemophilous \\
\hline Balsaminaceae & entomophilous & Myristicaceae & entomophilous \\
\hline Begoniaceae & entomophilous & Myrsinaceae & entomophilous \\
\hline Bignoniaceae & $\begin{array}{l}\text { entomophilous, } \\
\text { or ornithophilous, } \\
\text { or cheiropterophilous }\end{array}$ & Myrtaceae & $\begin{array}{l}\text { entomophilous, } \\
\text { or ornithophilous }\end{array}$ \\
\hline Bombacaceae & cheiropterophilous & Nyctagynaceae & entomophilous \\
\hline Boraginaceae & entomophilous & Ochnaceae & entomophilous \\
\hline Brassicaceae & $\begin{array}{l}\text { anemophilous, } \\
\text { or entomophilous }\end{array}$ & Olacaceae & entomophilous \\
\hline Buddleyaceae & $\begin{array}{l}\text { entomophilous, } \\
\text { or ornithophilous }\end{array}$ & Oleaceae & $\begin{array}{l}\text { anemophilous (mostly), } \\
\text { or entomophilous }\end{array}$ \\
\hline Burseraceae & entomophilous & Orobanchaceae & entomophilous \\
\hline Caesalpiniaceae & entomophilous; & Palmae & $\begin{array}{l}\text { entomophilous (mostly), } \\
\text { or anemophilous }\end{array}$ \\
\hline Campanulaceae & entomophilous & Pandanaceae & $\begin{array}{l}\text { anemophilous (mostly), } \\
\text { or entomophilous, } \\
\text { or ornithophilous, } \\
\text { or cheiropterophilous }\end{array}$ \\
\hline Capparidaceae & entomophilous & Passifloraceae & entomophilous \\
\hline
\end{tabular}


Table 2. Continued.

\begin{tabular}{|c|c|c|c|}
\hline Family & Pollination system & Family & Pollination system \\
\hline Caryophyllaceae & entomophilous & Phyllanthaceae & entomophilous \\
\hline Casuarinaceae & anemophilous & Plantaginaceae & $\begin{array}{l}\text { anemophilous, } \\
\text { or anemophilous } \\
\text { and entomophilous }\end{array}$ \\
\hline Celastraceae & entomophilous & Poaceae & $\begin{array}{l}\text { anemophilous } \\
\text { (exclusively) }\end{array}$ \\
\hline Chrysobalanaceae & $\begin{array}{l}\text { entomophilous, } \\
\text { or cheiropterophilous }\end{array}$ & Podocarpaceae & anemophilous \\
\hline Clusiaceae & $\begin{array}{l}\text { entomophilous, } \\
\text { or ornithophilous }\end{array}$ & Polygalaceae & entomophilous \\
\hline Cochlospermaceae & entomophilous & Polygonaceae & $\begin{array}{l}\text { anemophilous, or } \\
\text { entomophilous }\end{array}$ \\
\hline Combretaceae & $\begin{array}{l}\text { entomophilous, } \\
\text { or ornithophilous }\end{array}$ & Primulaceae & entomophilous \\
\hline Commelinaceae & entomophilous & Proteaceae & $\begin{array}{l}\text { entomophilous, or } \\
\text { ornithophilous, or } \\
\text { cheiropterophilous (?), } \\
\text { or by unusual means } \\
\text { (notably by small } \\
\text { marsupials and rodents) }\end{array}$ \\
\hline Connaraceae & $\begin{array}{l}\text { autogamous } \\
\text { or entomophilous }\end{array}$ & Ranunculaceae & $\begin{array}{l}\text { anemophilous, } \\
\text { or entomophilous }\end{array}$ \\
\hline Convolvulaceae & entomophilous & Resedaceae & entomophilous \\
\hline Crassulaceae & entomophilous & Rhamnaceae & entomophilous \\
\hline Cucurbitaceae & entomophilous & Rhizophoraceae & $\begin{array}{l}\text { anemophilous, } \\
\text { or entomophilous }\end{array}$ \\
\hline Cupressaceae & anemophilous & Rosaceae & $\begin{array}{l}\text { anemophilous } \\
\text { (occasionally), or } \\
\text { entomophilous } \\
\text { (usually) }\end{array}$ \\
\hline Dichapetalaceae & entomophilous & Rubiaceae & entomophilous \\
\hline Dilleniaceae & entomophilous & Rutaceae & entomophilous \\
\hline Dioscoreaceae & entomophilous & Salicaceae & $\begin{array}{l}\text { anemophilous, } \\
\text { or entomophilous }\end{array}$ \\
\hline Dipsacaceae & entomophilous & Salvadoraceae & entomophilous \\
\hline Ebenaceae & entomophilous & Sapindaceae & entomophilous \\
\hline Ephedraceae & $\begin{array}{l}\text { anemophilous, } \\
\text { or entomophilous }\end{array}$ & Sapotaceae & entomophilous \\
\hline Ericaceae & $\begin{array}{l}\text { entomophilous } \\
\text { (usually?) }\end{array}$ & Scrophulariaceae & $\begin{array}{l}\text { entomophilous, } \\
\text { or ornithophilous }\end{array}$ \\
\hline Euphorbiaceae & entomophilous & Simaroubaceae & $\begin{array}{l}\text { entomophilous, } \\
\text { or ornithophilous }\end{array}$ \\
\hline Fabaceae & $\begin{array}{l}\text { entomophilous, } \\
\text { or ornithophilous, } \\
\text { or cheiropterophilous }\end{array}$ & Solanaceae & entomophilous \\
\hline Flacourtiaceae & entomophilous & Sphenocleaceae & entomophilous \\
\hline Gentianaceae & entomophilous & Sterculiaceae & entomophilous \\
\hline
\end{tabular}


Table 2. Continued.

\begin{tabular}{|c|c|c|c|}
\hline Family & Pollination system & Family & Pollination system \\
\hline Geraniaceae & entomophilous & Tamaricaceae & $\begin{array}{l}\text { entomophilous, } \\
\text { or anemophilous }\end{array}$ \\
\hline Gesneriaceae & $\begin{array}{l}\text { entomophilous, } \\
\text { or ornithophilous, } \\
\text { or cheiropterophilous }\end{array}$ & Thymeleaceae & entomophilous \\
\hline Hippocrateaceae & entomophilous & Tiliaceae & enthomophilous \\
\hline Hymenocardiaceae & $\begin{array}{l}\text { entomophilous (mostly), } \\
\text { or anemophilous }\end{array}$ & Tribulaceae & entomophilous \\
\hline Hypericaceae & entomophilous & Ulmaceae & entomophilous \\
\hline Icacinaceae & entomophilous & Urticaceae & anemophilous \\
\hline Irvingiaceae & entomophilous & Verbenaceae & entomophilous \\
\hline Lamiaceae & $\begin{array}{l}\text { entomophilous } \\
\text { or ornithophilous }\end{array}$ & Vitaceae & $\begin{array}{l}\text { entomophilous (mostly), } \\
\text { or anemophilous }\end{array}$ \\
\hline Lecythidaceae & entomophilous & Zygophyllaceae & entomophilous \\
\hline Portulaceae & entomophilous & & \\
\hline
\end{tabular}
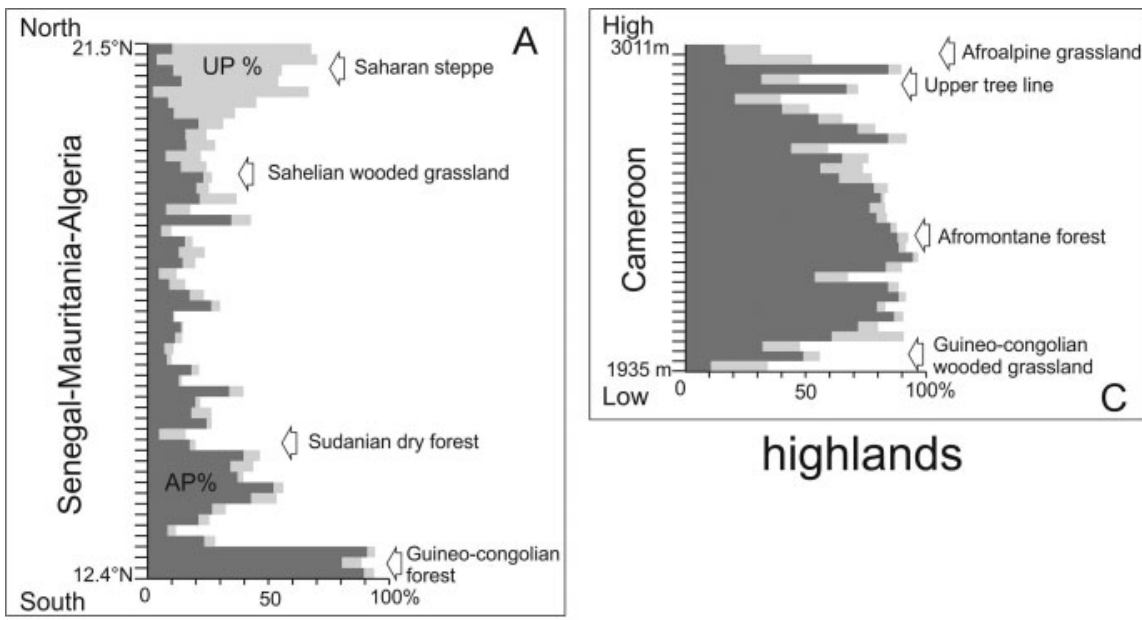

highlands

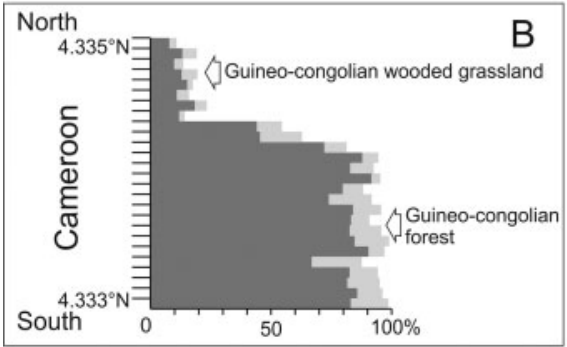

lowlands

Figure 2. Modern pollen deposition in three different sectors of northern Africa: (A): a South-North transect in Senegal-Mauritania-Algeria (Lézine and Hooghiemstra 1990), (B): the Kandara forest-savanna transect in Southern Cameroon (Vincens et al. 2000), and (C): an altitudinal transect in the Cameroon highlands (Verlhac et al. 2018). Percentages calculated against a sum excluding fern spores, aquatics and Cyperaceae pollen. Dark grey: AP\%. Light grey: UP\%. 


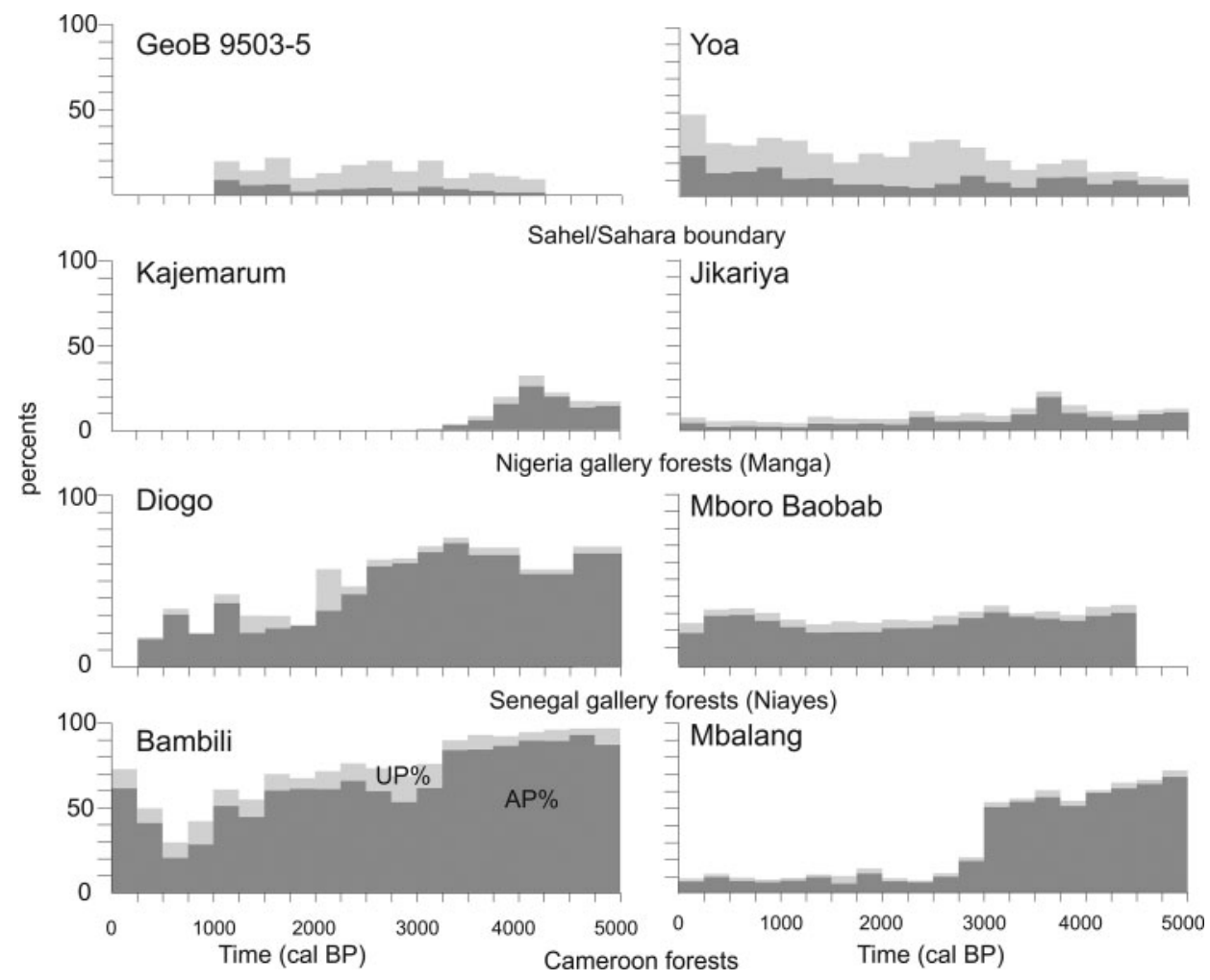

Figure 3. Percentages of Arboreal (AP) and Undifferentiated pollen types (UP) in selected sites from northern Africa from $5000 \mathrm{cal} \mathrm{yr} \mathrm{BP} \mathrm{to} \mathrm{the} \mathrm{present.} \mathrm{In} \mathrm{order} \mathrm{to} \mathrm{facilitate} \mathrm{the} \mathrm{comparison} \mathrm{between} \mathrm{sites,} \mathrm{data} \mathrm{are} \mathrm{averaged} \mathrm{by} 250$-years' time bins.

gaps linked to recent settlements. A slightly different pattern is observed in the montane forests Cameroon (Figure 2C; Verlhac et al. 2018). As expected, AP reach high values, up to $90 \%$, within the forest. However, they strongly vary, reflecting the highly heterogeneous forest cover (Momo Solefack 2009) (Figure 2C). This is particularly the case at higher elevations where the trees are irregularly distributed and the upper tree line is often patchy due to marked topography. Afroalpine grasslands at the top of the mountains and wooded grasslands below the forest block show AP averaging $15 \%$ and $10 \%$, respectively.

\subsection{THE HOLOCENE POLLEN SEQUENCES}

Vincens et al. (1999) first reviewed the equatorial forest response at the end of the AHP. They showed that the lowland forests changed in nature from rain or swamp forests to woodlands or secondary forests characterized by an increase in light demanding trees. While the timing of this change is remarkably coherent in the lowlands of Cameroon at around $2400 \mathrm{cal} \mathrm{yr}$ BP (Lézine et al. 2013b and reference therein), it varies in Congo within a time interval from 3800 and $1800 \mathrm{cal}$ yr BP according to local hydrological conditions (Vincens et al. 1999). In mountain areas, a clear signal of forest disruption occurred at 3300-3000 cal yr BP (Figure 3): AP values abruptly fell from 50 to $9 \%$ in the Adamawa plateaus (Mbalang) and then remained below $11 \%$ up to the present day. At higher elevations (Bambili), AP decreases from $84 \%$ to $54 \%$ at $3300 \mathrm{cal} \mathrm{yr}$ 


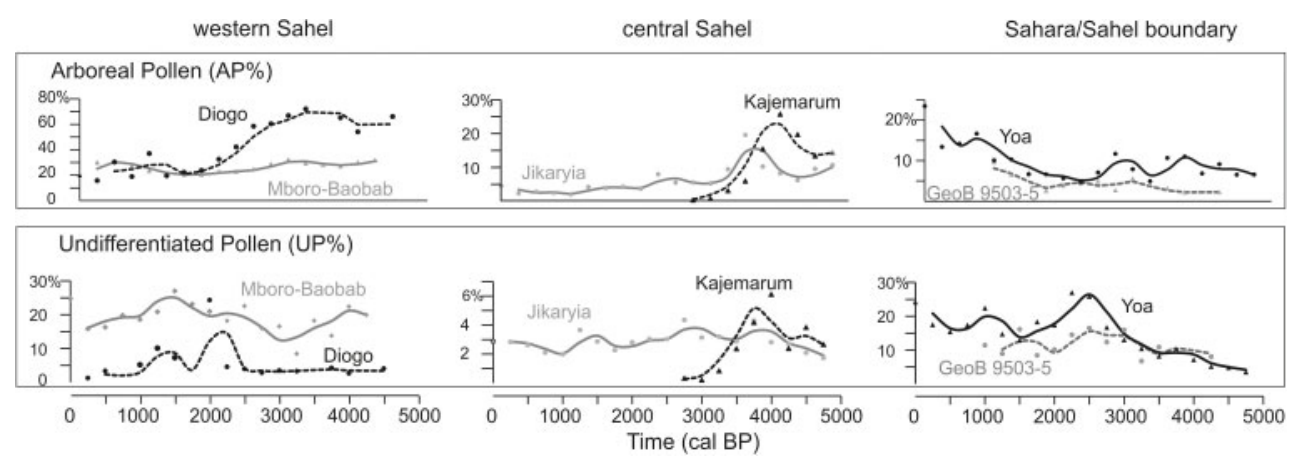

Figure 4. Arboreal pollen percentage (AP\%) and undifferentiated pollen percentage (UP\%) from selected sites from the Sahara and the Sahel. Dashed lines show the second order running average.

BP and then remained at this level up to $2500 \mathrm{cal}$ yr BP. AP subsequently increased again to a maximum of $65 \%$ indicating a later forested phase, albeit less developed compared to that of the AHP. This second phase of forest development ended during the last millennium.

In the Sahel, the pollen diagrams testify to a contrasting situation: in the west, near the Atlantic coast, AP\% were remarkably high during the Holocene forest phase indicating dense gallery forests in the coastal region (Diogo). AP decreased from $72 \%$ to $19 \%$ between 3250 and 1250 cal yr BP through a well-marked threshold at 2500 BP characterized by a drop of about $20 \%$. In the same region however, Mboro-Baobab did not record such an evolution and AP values displayed rather constant percentages during the last 5000 years, only slightly fluctuating between 30 and 20\%. In the central Sahel, AP never reached percentages as high as those recorded in the west, even during the AHP reflecting poorly developed gallery forests around water bodies. The maximum of AP at Kajemarum and Jikaryia in the Manga region of northern Nigeria did not exceed $26 \%$ and $19 \%$, respectively. At Kajemarum, AP definitively disappeared at 3000 cal yr BP. At Jikaryia, the transition between the Holocene and the present landscape was less contrasted though a slight decrease in AP\% was observed at the same time. At the Sahara/Sahel transition (Yoa, GeoB 95013-5) AP were constantly less than 23\% during the AHP. At Yoa, the retreat of tropical plant species (e.g. Celtis, Piliostigma, Grewia) and the establishment of desert conditions at the end of the AHP occurred in two phases at 4700 and 2700 cal yr BP, respectively (Lézine et al. 2011). This transition occurred in a context of poorly developed tree cover and is therefore not reflected by our AP index. Interestingly, AP\% slightly increased during the last few centuries which may reflect increased anthropogenic influence, for instance the establishment of palm tree plantations at Yoa (Lézine et al. 2011), or the occurrence of episodic humid events in the Senegal River Basin (Bouimetarhan et al. 2009). In order to refine the timing and structure of the end of the AHP in the Sahel, we plotted the undifferentiated pollen types (UP) (Figure 4) that are especially abundant in the most arid regions as shown in the modern samples (Figure 2). Three sectors of the Sahara and the Sahel emerge from the examination of UP \%: at the Sahara/Sahel boundary, the UP \% gradually increased from 5000 cal yr BP (or even before) to the present with a peak at 2700 cal yr BP. A roughly similar trend is observed in the Central Sahel. Here they were present from $4000 \mathrm{cal}$ yr BP and then remained constant throughout the last millennia. In contrast, UP \% increased much later, since 2700 cal yr BP in the western Sahel.

\subsection{DISCUSSION}

Our study illustrates one of the major problems of tropical palynology: can the abundance of trees and grasses in the landscape be described using a simple index: the percentage of arboreal 
pollen? Open landscapes dominate in Africa today between $30^{\circ} \mathrm{S}$ and $30^{\circ} \mathrm{N}$ with the exception of the equatorial mangrove, and afromontane forests. These open landscapes are of various types, ranging from dry forests, to woodlands, wooded grasslands and grasslands (White 1983). The particularities of pollen production and dispersal of tropical plants mean that trees are often under-represented in pollen spectra, making distinction between these types of vegetation difficult. Based on the modern samples (Figure 2), we have considered three AP\% categories to characterize the late Holocene landscape of northern Africa (Figures 5 and 6): (i) AP higher than $45 \%$ corresponding to a dense tree cover, (ii) AP lower than $15 \%$ indicating grass-dominated landscapes, and (iii) intermediate values $(15<\mathrm{AP}<45 \%)$, secondary/dry forests. Figure 5 shows that dense forest stands remained developed in mangroves along the coast of the Gulf of Guinea, in the western Sahel and in the Cameroon highlands well after the establishment of xeric conditions at the end of the AHP. Surprisingly, it suggests that there was no transition from forested to open landscapes from south to north throughout northern Africa with open landscapes dominating largely from 5000 to $c .3000$ cal yr BP north of $10^{\circ} \mathrm{N}$. The absence of intermediate tree cover between forests and open landscapes is likely an artefact due to the difficulties evoked in distinguishing woodlands from wooded grasslands and grasslands. While different kinds of open environments are difficult to infer from $\mathrm{AP} \%$, it is even more difficult to derive related climatic factors. For instance, modern AP\% are higher at Yoa in the Saharan steppe, where the annual rainfall does not exceed $7 \mathrm{~mm}(23 \%)$ than at Mbalang in the Sudanian wooded grassland, where it averages 1500 $1600 \mathrm{~mm}$ (6.5\%). Environmental reconstructions in such grass-dominated landscapes are thus particularly challenging and new methodological approaches such as those developed by Sugita (2007) are crucial for a better estimation of regional vegetation proportions (See Gaillard et al., this volume). Despite this major limitation and the purely qualitative aspect of our approach, two key results emerge from our review (6.7.1 and following).

\subsubsection{Abrupt forest collapses or gradual establishment of xeric conditions?}

In densely forested areas from western Sahel (Diogo) and the Cameroon Highlands (Bambili, Mbalang), AP\% permits identification of the tipping points between forested and non-forested (or less-forested) states that occurred at times, varying according to altitude and hydrological conditions, between 3300 and $2500 \mathrm{cal} \mathrm{yr}$ BP (Figure 3). However, the determination is only qualitative since the evaluation of its magnitude depends mainly on the pollen productivity and dispersion of tropical trees (see Gaillard et al., this volume). Abrupt forest collapse most certainly originated from the middle Holocene, when an increased seasonality in rainfall was established (Vincens et al. 2010). At Bambili, the progressive destabilization of the forest is thought to have originated from the ' 8.2 event', which could thus be considered as the 'early warning signal' (Lenton 2011) of the environmental crisis that took place several millennia later, at $3300 \mathrm{cal} \mathrm{yr}$ BP (Lézine et al. 2013a). Unlike these sites, where a threshold was abruptly crossed leading to the collapse of the forests, the establishment of an open landscape at the end of the AHP was gradual (Figure 4); tree cover decreased gradually in already arid areas, particularly in the central Sahel. This supports the interpretations by Kröpelin et al. (2008) that the transition to xeric conditions at the end of the AHP was a gradual one. Consequently, pollen data from the Sahel do not support the earlier hypotheses of an abrupt environmental change at the end of the AHP as proposed by de Menocal et al. (2000).

\subsubsection{A complex pattern of environmental change}

Changes in distribution of trees across the landscape was not merely latitudinal following a southnorth gradient of decreasing precipitation (Figure 5). The most striking feature is the difference between the central and western Sahel. We therefore consider two separate transects, one along the west coast and the other in central northern Africa. Forests widely developed in the west. 


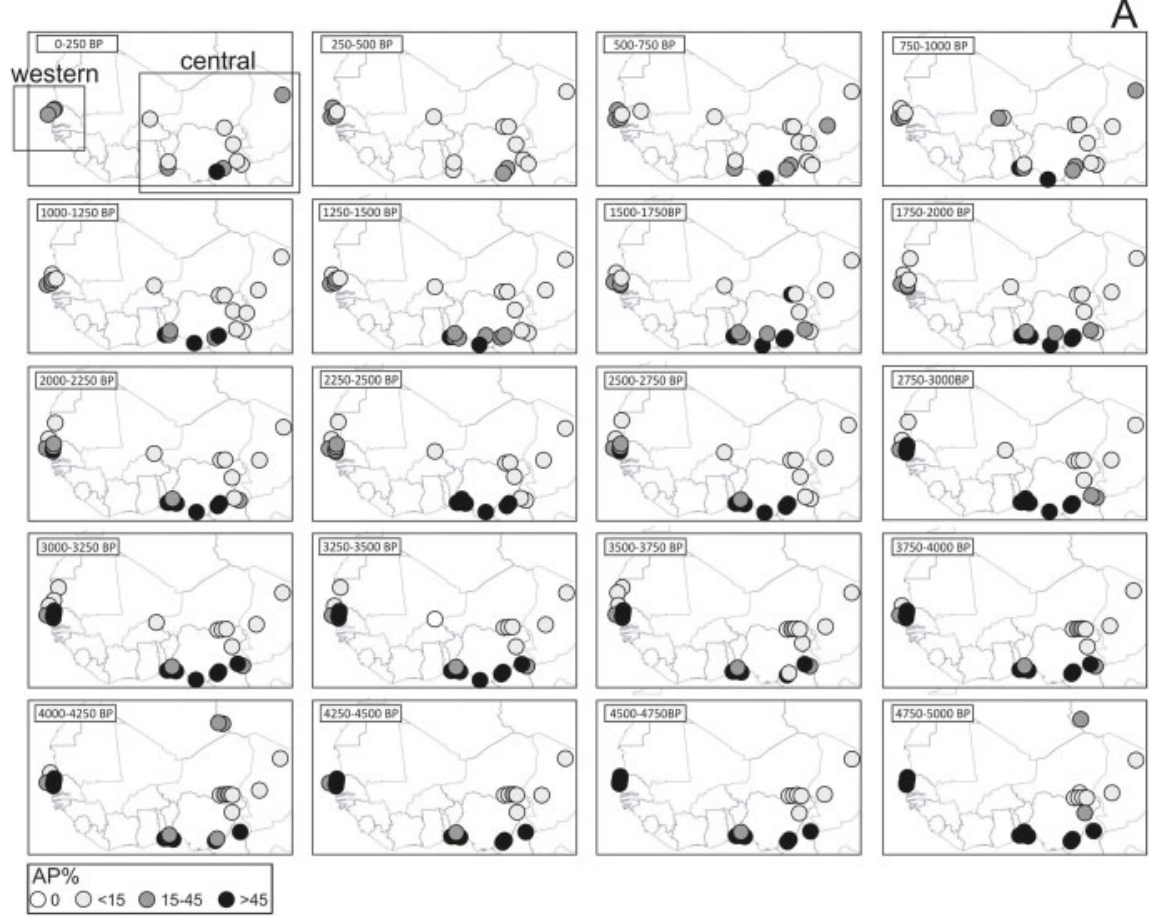

B
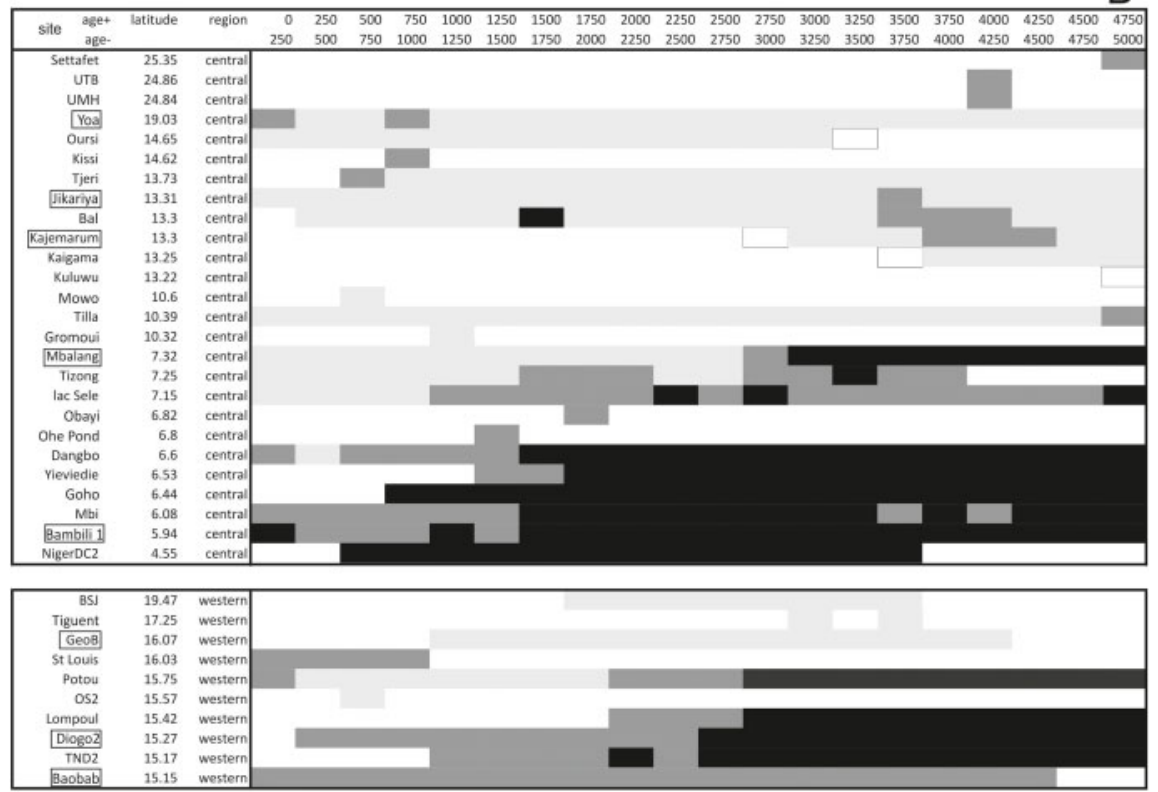

Figure 5. (A) Spatial distribution of tree pollen percentages from $5000 \mathrm{cal} \mathrm{yr} \mathrm{BP}$ to the present in northern Africa. Three categories are considered with $\mathrm{AP}>45 \%$ showing dense tree cover, $15<\mathrm{AP}<45 \%$ intermediate tree cover and AP $<15 \%$ sparse tree cover. (B) Patterns of tree cover change according to latitude in the two sectors defined in Figure 1 . The selected sites are indicated on the left column by a box. 


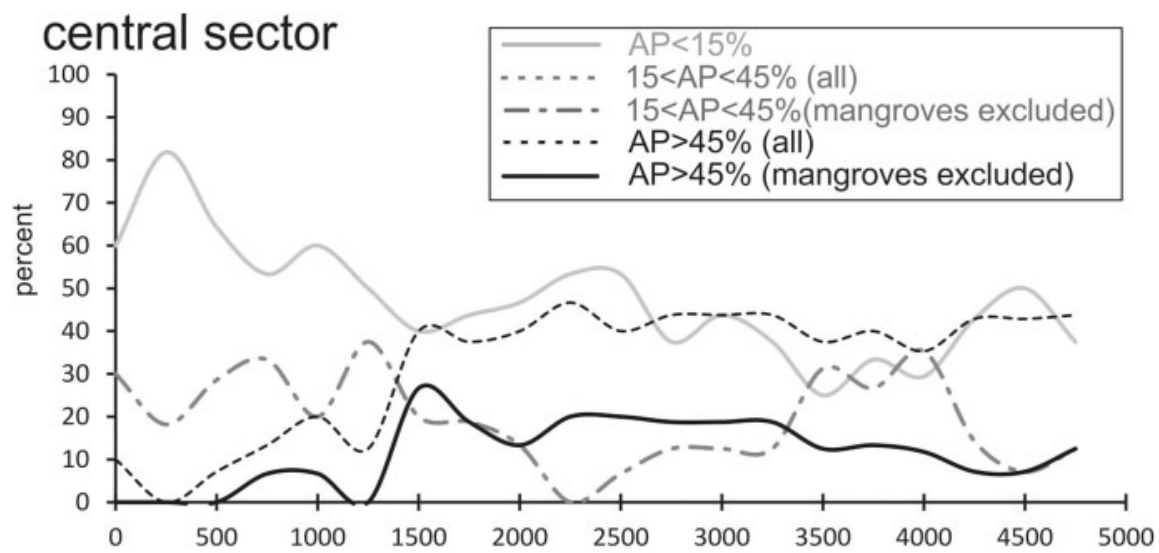

\section{western sector}

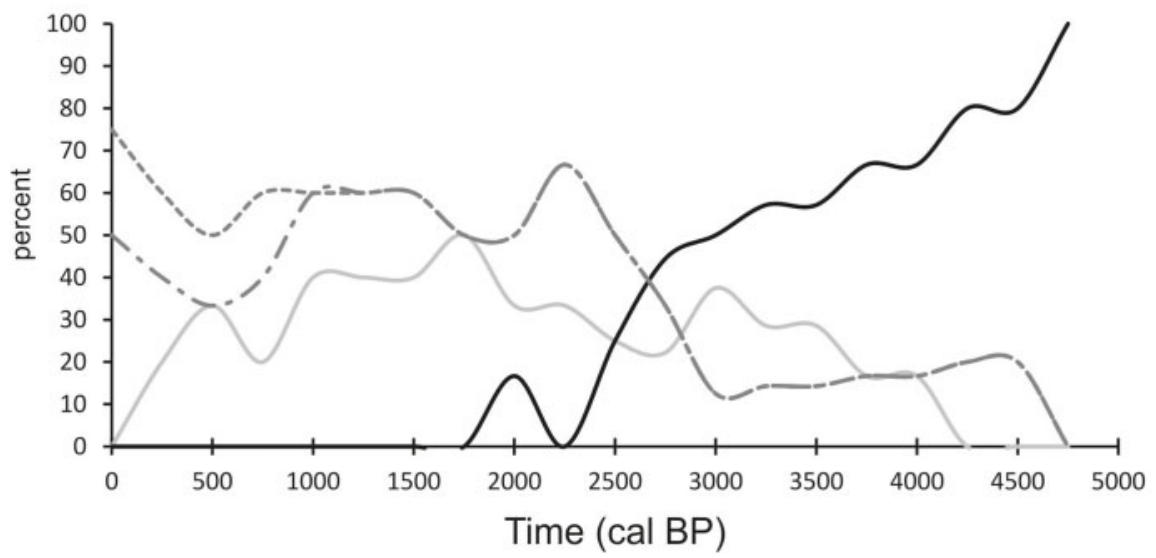

Figure 6. Timing of landscape change in the western (on the left) and central (on the right) sectors of northern Africa. The curves show the number of sites in the categories defined by $\mathrm{AP} \%$ in northern Africa $(\mathrm{AP}=\mathrm{O}, \mathrm{AP}<15 \%$, $15<\mathrm{AP}<45 \%,>45 \%$ ). Data are expressed in per cent of the total of sites present in each time bin (cf. Figure $5 \mathrm{~B}$ ).

Their expansion reached approximately $16^{\circ} \mathrm{N}$, i.e. the mouth of the Senegal River. In contrast, forests only occurred along the coast and in the highlands in central Africa. Trees were rare north of $10^{\circ} \mathrm{N}$ in the Sahel, except during a time interval spanning from 4500 to $3500 \mathrm{cal} \mathrm{yr} \mathrm{BP}$ in the Manga region $\left(13^{\circ} \mathrm{N}\right)$ and in the central Saharan massifs in southern Libya $\left(25^{\circ} \mathrm{N}\right)$ where they slightly increased (Figures 5 and 6).

Despite the limited number of sites in both sectors clear patterns can be discerned. In the western sector, the major change in forest cover occurred from 3000 to $2250 \mathrm{cal} \mathrm{yr}$ BP. This is shown by the opposing trends between the number of sites with AP values above $45 \%$, which were gradually decreasing in number and those with AP values ranging from 15 to $45 \%$, which were gradually increasing. Sparse tree cover became gradually commoner over the western sector from 4250 cal yr BP with the modern landscape composed of woodlands and wooded grasslands being definitively established after $1750 \mathrm{cal}$ yr BP. Unlike the western sector, sites with sparse tree cover dominated the central sector throughout the last 5000 years. The number of such sites progressively increased in two phases respectively dated 3500 and $1500 \mathrm{cal}$ yr BP. Sites with 
dense tree cover were restricted to the Cameroon Highlands and the mangrove areas along the Gulf of Guinea. In both sectors, they declined from 1500 cal yr BP onwards. The most striking result of our study is the behaviour of sites with intermediate tree cover. As already noted, trees increased in the Manga sector of the Sahel around $3800 \mathrm{cal}$ yr BP due to the recovery of tropical taxa during a short wet phase (Waller et al. 2007). After $3500 \mathrm{cal}$ yr BP, trees disappeared from the Manga sector. Elsewhere in the central sector of northern Africa, the number of sites with intermediate and sparse tree cover increased from $2250 \mathrm{cal}$ yr BP onwards.

\subsection{CONCLUSIONS}

Reconstructing vegetation cover from AP\% is highly challenging, particularly given the predominantly open vegetation types that are widely distributed in northern Africa from the Sudanian dry forests to the Sahelian wooded grasslands and Saharan grasslands. Despite this caveat, our review shows that the landscape response to the end of the AHP was far from homogeneous particularly in the Sahel where a clear east-west gradient of tree cover change is indicated, the central Sahel being notably poor in tree species as shown for instance in the Lake Chad (Tjeri) and the Niger bend (Oursi, Kissi) areas. In areas where forests were well developed during the AHP, i.e. in the south and west, the establishment of the modern landscape was abrupt with a threshold crossed between 3300 and $2500 \mathrm{cal}$ yr BP according to local conditions. Elsewhere in northern Africa the switch from tree $\left(\mathrm{C}_{3}\right)$ to grass $\left(\mathrm{C}_{4}\right)$ dominated landscapes occurred at approximately the same time, but more gradually. This review allows the timing of the ecosystem response at the end of the AHP be identified, which was remarkably synchronous throughout northern Africa, in contrast to hydrological data, which suggest a time transgressive end to the AHP (Shanahan et al. 2015).

\section{ACKNOWLEDGEMENTS}

This work contributes to the ACCEDE ANR Belmont Forum project ((18 BELM 0001 05). Thanks are due to M.J. Gaillard (Kalmar University, Sweden) for constructive comments on the manuscript and the African Pollen Database for data access. AML and KL are funded by CNRS, LD by the University of Bremen and IB by the BMF grant PMARS2015-100.

\section{REFERENCES}

Anthony, E., 1989, Chenier plain development in Northern Sierra Leone, West Africa. Marine Geology 90, pp. 297-309, 10.1016/0025-3227(89)90132-1.

Ballouche, A., 1997, Dynamique des paysages végétaux sahélo-soudaniens et pratiques agropastorales à l'Holocène: exemples du Burkina Faso. Monographies-Bulletin de l'Association de Géographes Français, Paris.

Ballouche, A. and Neumann, K., 1995, A new contribution to the Holocene vegetation history of the West African Sahel: pollen from Oursi, Burkina Faso and charcoal from three sites in northeast Nigeria. Vegetation History and Archaeobotany, 4, pp. 31-39, 10.1007/BF00198613.

Bouimetarhan, I., Dupont, L., Schefuß, E., Mollenhauer, G., Mulitza, S. and Zonneveld, K., 2009, Palynological evidence for climatic and oceanic variability off NW Africa during the late Holocene. Quaternary Research, 72, pp. 188-197, 10.1016/j.yqres.2009.05.003.

Dallmeyer, A., Claussen, M., Lorenz, S.J. and Shanahan, T., 2020, The end of the African Humid Period as seen by a transient comprehensive Earth system model simulation of the last 8000 years. Climate of the Past, 16, pp. 117-140, 10.5194/cp-16-117-2020. 
Delneuf, M. and Médus, J., 1997, Comparaison de deux environnements anthropisés de la période protohistorique du Nord-Cameroun. In L'Homme et le milieu végétal dans le bassin du Lac Tchad: Séminaire du Réseau Méga-Tchad, edited by Barreteau, D., Dognin, R. and von Graffenried, C. (Paris: ORSTOM), pp. 145-170.

De Menocal, P., Ortiz, J., Guilderson, T., Adkins, J., Sarnthein, M., Baker, L. and Yarusinsky, M., 2000, Abrupt onset and termination of the African Humid Period: rapid climate responses to gradual insolation forcing. Quaternary Science Reviews, 19(1-5), pp. 347-361, 10.1016/S0277-3791(99)00081-5.

Elenga, H., Schwartz, D. and Vincens, A., 1994, Pollen evidence of late Quaternary vegetation and inferred climate changes in Congo. Palaeogeography, Palaeoclimatology, Palaeoecology 109, pp. 345-356, 10.1016/0031-0182(94)90184-8.

Elenga, H., Schwartz, D., Vincens, A., Bertaux, J., de Namur, C., Martin L., Wirrmann, D. and Servant M., 1996, Diagramme pollinique Holocène du lac Kitina (Congo): mise en évidence de changements paléobotaniques et paléoclimatiques dans le massif forestier du Mayombe. Comptes-Rendus de l'Académie des Sciences, Paris 323, IIA, pp. 403-410.

Feller, C., Médus, J., Paycheng, C. and Chavane, B., 1981, Etude pédologique et palynologique d'un site protohistorique de la moyenne vallée du fleuve Sénégal. Palaeoecology of Africa, 13, pp. 235-247.

Fofana, C.A.K., Sow, E. and Lézine, A.-M., 2020, The Senegal River during the last millennium. Review of Palaeobotany and Palynology, 275, p. 104175, 10.1016/j.revpalbo.2020.104175.

Gaillard, M.-J., Githumbi, E., Achoundong, G., Lézine, A.-M., Hély, C., Lebamba, J., Marquer, L., Mazier, F., Li, F., Sugita, S., this volume, The challenge of pollen-based quantitative reconstruction of Holocene plant cover in subtropical and tropical regions - a review and a pilot study in West Africa. Palaeoecology of Africa, 35, chapter 12, 10.1201/9781003162766-12.

Gajewski, K., Lézine, A.-M., Vincens, A., Delestan, A. and Sawada, M., 2002, Modern climatevegetation-pollen relations in Africa and adjacent areas. Quaternary Science Reviews, 21(1415), pp. 1611-1631, 10.1016/S0277-3791(01)00152-4.

Hedberg, O., 1954, A pollen analytical reconnaissance in tropical East Africa. Oikos, 5, pp. 137 $165,10.2307 / 3565157$.

Hély, C., Lézine, A.-M. and APD contributors, 2014, Holocene changes in African vegetation: tradeoff between climate and water availability. Climate of the Past, 10, pp. 681-686, 10.5194/cp-10-681-2014.

Krinner, G., Lézine, A.-M., Braconnot, P., Sepulchre, P., Ramstein, G., Grenier, C. and Gouttevin, I., 2012, A reassessment of lake and wetland feedbacks on the North African Hlocene climate. Geophysical Research Letters, 39(7), 10.1029/2012GL050992), article: L07701.

Kröpelin, S., Verschuren, D., Lézine, A.-M., Eggermont, H., Cocquyt, C., Francus, P., Cazet, J.P., Fagot, M., Rumes, B., Russell, J.M., Conley, D.J., Schuster, M., Von Suchodoletz, H., Engstrom, D.R., 2008, Climate-driven ecosystem succession in the Sahara: the past 6000 years. Science, 320(5877), pp. 765-768, 10.1126/science.1154913.

Lebamba, J., Vincens, A., Lézine, A.-M., Marchant, R. and Buchet, G., 2016, Forest-savannah dynamics on the Adamawa plateau (Central Cameroon) during the "African humid period" termination: A new high-resolution pollen record from Lake Tizong. Review of Palaeobotany and Palynology, 235, 129-139, 10.1016/j.revpalbo.2016.10.001.

Lemonnier, K., and Lézine, A.-M., this volume, Timing and nature of the end of the Holocene Humid Period in the Sahel: Insight from pollen data. Palaeoecology of Africa, 35, chapter: 5, 10.1201/9781003162766-5.

Lenton, T.M., 2011, Early warning of climate tipping points. Nature Climate Change,1(4), pp. 201-209, 10.1038/nclimate1143.

Lézine, A.-M., 1988, Les variations de la couverture forestière mésophile d'Afrique occidentale au cours de l'Holocène. Comptes Rendus de l'Académie des Sciences, Paris, 307(2), pp. 439-445. 
Lézine, A.-M., 1997, Evolution of the West African mangrove during the late Quaternary: a review. Géographie Physique et Quaternaire, 51, pp. 405-414, 10.7202/033139ar.

Lézine, A.-M. and Hooghiemstra, H., 1990. Land-sea comparisons during the last glacialinterglacial transition: pollen records from West Tropical Africa. Palaeogeography, Palaeoclimatology, Palaeoecology 79(3-4), pp. 313-331, 10.1016/0031-0182(90)90025-3.

Lézine, A.-M., Watrin, J., Vincens, A. and Hély, C., 2009, Are modern pollen data representative of West African vegetation? Review of Palaeobotany and Palynology, 156(3-4), pp. 265-276, 10.1016/j.revpalbo.2009.02.001.

Lézine, A.-M., Zheng, W., Braconnot, P. and Krinner, G., 2011, Late Holocene plant and climate evolution at Lake Yoa, northern Chad: Pollen data and climate simulations. Climate of the Past, 7, pp. 1351-1362, 10.5194/cp-7-1351-2011.

Lézine, A.-M., Assi-Kaudjhis, C. Roche, E., Vincens, A. and Achoundong, G., 2013a, Towards an understanding of West African montane forest response to climate change. Journal of Biogeography, 40(1), pp. 183-196, 10.1111/j.1365-2699.2012.02770.x.

Lézine, A.-M., Holl, A.F.C., Lebamba, J., Vincens, A., Assi-Khaudjis, C., Février, L. and Sultan, E, 2013b, Temporal relationship between Holocene human occupation and vegetation change along the northwestern margin of the Central African rainforest. Comptes Rendus Geoscience, 345(7-8), pp. 327-335, 10.1016/j.crte.2013.03.001.

Lézine, A.-M., Izumi, K. and Achoundong, G., 2021, Mbi Crater (Cameroon) illustrates the relations between mountain and lowland forests over the past 15,000 years in Western Equatorial Africa. Quaternary International, 10.1016/j.quaint.2020.12.014.

Maley, J., 2004, Le bassin du Tchad au Quaternaire récent: formations sédimentaires, paléoenvironnements et préhistoire. La question des paléotchads. In L'évolution de la végétation depuis deux millions d'années, edited by Sémah, A.-M. and Renault-Miskovsky, J. (Paris: Errance), pp. 179-217.

Maley, J. and Brenac, P., 1998, Vegetation dynamics, palaeoenvironments and climatic change in the forests of western Cameroon during the last 28,000 years BP. Review of Palaeobotany and Palynology 99, pp. 157-187, 10.1016/S0034-6667(97)00047-X.

Médus, J. and Barbey, C., 1979, Deux analyses polliniques de sédiments minéraux de Mauritanie méridionales. Association sénégalaise pour l'Etude du Quaternaire, Bulletin de Liaison, 5455, pp. 75-79.

Mercuri A.-M., Grandi G.T., Mariotti Lippi M. and Cremaschi M. (1998). New pollen data from the Uan Muhuggiag rockshelter (Libyan Sahara, VII-IV millennia BP). In Wadi Teshuinat Palaeoenvironment and prehistory in south-western Fezzan (Libyan Sahara). Survey and excavations in the Tadrart Acacus, Erg Uan Kasa, Messak Settafet and Edeyen of Murzuq, 1990-1995, edited by Cremaschi, M. and di Lernia, S. (Firenze, Edizioni All'Insegna del Giglio), pp. 107-122.

Mercuri, A.-M. and Grandi, G.T., 2001, Palynological analyses of the Late Pleistocene, Early Holocene and Middle Holocene layers. In Uan Tabu in the settlement history of the Libyan Sahara, Arid Zone Archaeology, Monographs 2, Ch. 10, edited by Garcea, E.A.A. (Firenze: Edizioni All'Insegna del Giglio), pp. 161-188.

Momo Solefack, M.C., 2009, Influence des activités anthropiques sur la végétation du Mont Oku (Cameroun). PhD Thesis, Université de Picardie, Amiens, France.

Ngomanda, A, Neumann, K, Schweizer, A and Maley, J., 2009, Seasonality change and the third millennium BP rainforest crisis in southern Cameroon (Central Africa). Quaternary Research, 71(3), pp.307-18, 10.1016/j.yqres.2008.12.002.

Njokuocha, R.C., 2012, Holocene pollen deposits and recent vegetation distribution of Obayi Lake, Nsukka. Quaternary international, 262, pp. 20-24, 10.1016/j.quaint.2011.10.033.

Njokuocha, R.C. and Akaegbobi, I.M., 2014, A contribution to the Holocene vegetation history of Nigeria: Pollen from Ohe Pond Nsukka, southeastern Nigeria. Quaternary International, 338, pp. 28-34, 10.1016/j.quaint.2013.07.036. 
Reynaud-Farrera, I., Maley, J. and Wirrmann, D., 1996. Végétation et climat dans les forêts du Sud-Ouest Cameroun depuis 4770 ans BP: analyse pollinique des sédiments du Lac Ossa. Comptes Rendus de l'Académie des Sciences, Paris, 322(II A), pp. 749-755.

Ritchie, J.C., 1995, Current trends in studies of long-term plant community dynamics. New Phytologist, 130(4), pp. 469-494, 10.1111/j.1469-8137.1995.tb04325.x.

Salzmann, U. and Hoelzmann, P., 2005, The Dahomey Gap: an abrupt climatically induced rain forest fragmentation in West Africa during the late Holocene. The Holocene, 15(2), pp. 190 199, 10.1191/0959683605hl799rp.

Salzmann, U. and Waller, M., 1998, The Holocene vegetational history of the Nigerian Sahel based on multiple pollen profiles. Review of Palaeobotany and Palynology, 100, pp. 39-72, 10.1016/S0034-6667(97)00053-5.

Salzmann, U., Hoelzmann, P. and Morczinek, I., 2002, Late Quaternary climate and vegetation of the Sudanian zone of northeast Nigeria. Quaternary Research, 58(1), pp. 73-83, 10.1006/qres.2002.2356.

Schulz, E., 1980, Zur Vegetation der östlichen zentralen Sahara und zu ihrer Entwicklung im Holozän. Würzburger Geographische Arbeiten 51.

Shanahan, T.M., McKay, N.P., Hughen, K.A., Overpeck, J.T., Otto-Bliesner, B., Heil, C.W., King, J., Scholz, C.A. and Peck, J., 2015, The time-transgressive termination of the African Humid Period. Nature Geoscience, 8(2), pp. 140-144, 10.1038/ngeo2329.

Sowunmi, M.A., 1981, Nigerian vegetational history from the Late Quaternary to the Present day. Palaeoecology of Africa, 13, pp. 217-234.

Stuiver, M., Reimer, P.J., and Reimer, R.W., 2020, CALIB 7.1 [WWW program] at http://calib.org, accessed 2020-6-9.

Sugita, S., 2007, Theory of quantitative reconstruction of vegetation I: pollen from large sites REVEALS regional vegetation composition. The Holocene, 17(2), pp. 229-241, $10.1177 / 0959683607075837$.

Tossou, M.G., 2002, Recherche palynologique sur la végétation Holocène du Sud-Bénin (Afrique de l'Ouest). PhD Thesis, Université de Lomé, Togo.

Trochain, J., 1940, Contribution à l'étude de la végétation du Sénégal. (Paris: LAROSE)

Verlhac, L., Izumi, K., Lézine, A.-M., Lemonnier, K., Buchet, G., Achoundong, G. and Tchiengué, B., 2018, Altitudinal distribution of pollen, plants and biomes in the Cameroon highlands. Review of Palaeobotany and Palynology, 259, pp. 21-28, 10.1016/j.revpalbo.2018.09.011.

Vincens, A., Buchet, G., Servant, M. and ECOFIT Mbalang collaborators, 2010, Vegetation response to the "African Humid Period" termination in Central Cameroon $\left(7^{\circ} \mathrm{N}\right)-$ new pollen insight from Lake Mbalang. Climate of the Past, 6, pp. 281-294, 10.5194/cp-6-281-2010.

Vincens, A., Dubois, M.A., Guillet, B., Achoundong, G., Buchet, G., Beyala, V.K.K., De Namur, C. and Riera, B., 2000, Pollen-rain-vegetation relationships along a forest-savanna transect in southeastern Cameroon. Review of Palaeobotany and Palynology, 110(3-4), pp. 191-208, 10.1016/S0034-6667(00)00009-9.

Vincens, A., Lézine, A.-M., Buchet, G., Lewden, D. and Le Thomas, A., 2007, African pollen database inventory of tree and shrub pollen types. Review of Palaeobotany and Palynology, 145(1-2), pp. 135-141, 10.1016/j.revpalbo.2006.09.004.

Vincens, A., Schwartz, D., Elenga, H., Reynaud-Farrera, I., Alexandre, A., Bertaux, J., Mariotti, A., Martin, L., Meunier, J.D., Nguetsop, F. and Servant, M., 1999, Forest response to climate changes in Atlantic Equatorial Africa during the last 4000 years BP and inheritance on the modern landscapes. Journal of Biogeography, 26(4), pp. 879-885, 10.1046/j.1365-2699.1999. 00333.x.

Waller, M.P., Street-Perrott, F.A. and Wang, H., 2007, Holocene vegetation history of the Sahel:pollen, sedimentological andgeochemical data from Jikariya Lake,north-eastern Nigeria. Journal of Biogeography, 34, pp. 1575-1590, 10.1111/j.1365-2699.2007.01721.x. 
Watrin, J., Lézine, A.-M., Gajewski, K. and Vincens, A., 2007, Pollen-plant-climate relationships in sub-Saharan Africa. Journal of Biogeography, 34(3), pp. 489-499, 10.1111/j.13652699.2006.01626.x.

Watrin, J., Lézine, A.-M., and Hély, C., 2009. Plant migration and ecosystems at the time of the "green Sahara". Comptes Rendus Geosciences 341, 656-670, 10.1016/j.crte.2009.06.007.

Watson, L. and Dallwitz, M.J., 1992 onwards, The families of flowering plants: descriptions, illustrations, identification, and information retrieval. Version: 2nd May 2020. deltaintkey.com.

White, F., 1983, The Vegetation of Africa (Paris: UNESCO). 


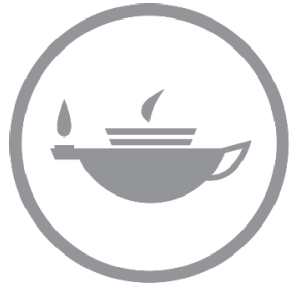

Taylor \& Francis Taylor \& Francis Group http://taylorandfrancis.com 